\title{
Damming effects on upstream riparian and aquatic vegetation: the case study of Nazzano (Tiber River, central Italy)
}

\author{
I. Tombolini ${ }^{(1)}$, G. Caneva ${ }^{(1)}$, L. Cancellieri ${ }^{(1)}$, S. Abati ${ }^{(1)}$, S. Ceschin ${ }^{(1), \star}$
}

Received April 28, 2013

Revised September 25, 2013

Accepted November 5, 2013

Key-words:

\section{ABSTRACT}

damming, man-made

wetland, hydrogeomorphic change, diachronic analysis, river vegetation
In the Mediterranean region, the majority of watercourses have undergone hydrogeomorphic alterations, mainly due to flow regulation such as damming. Despite this, few investigations analyzing dam impact on upstream river vegetation exist. In this study, we analyzed the temporal vegetation changes occurring along the Tiber River in Nazzano (Rome), as a consequence of the construction of a dam in 1956. We examined which communities are more sensitive to this anthropic alteration of the river ecosystem. An evaluation of how and with what timing these communities varied their extension as a result of such alteration is provided. Moreover, the role of the hydrogeomorphic alterations on the evolution of the river vegetation, linked to the management of this dam as a run-of-the-river impoundment, was analyzed. Our results show the main vegetation changes occurred during the first decades after the dam construction. Indeed, the dam operation caused significant local expansion of the upstream river waters, causing the flooding of most of the surrounding lands, and the formation of new sub-lentic wetlands. The altered hydrogeomorphic conditions favored the development of natural riparian and macrophyte communities typical of lacustrine ecosystems and therefore mostly different from those expected for the analyzed river typology. The changes in extension over time of these vegetation communities highlight their close relation to the alteration of some hydrological parameters especially affecting the river water level.

\section{RÉSUMÉ}

Effets d'un barrage sur la végétation riparienne et aquatique en amont : l'étude de cas de Nazzano (Tibre, Italie centrale)

Mots-clés : barrage, zones humides artificielles, changement hydrogéomorphologique,
Dans la région méditerranéenne, la majorité des cours d'eau a subi des modifications hydrogéomorphologiques, principalement causées par la régulation de l'écoulement comme dans le cas de barrages. Malgré cela, peu d'analyses de l'impact du barrage sur la végétation de la rivière en amont existent. Dans cette étude, nous avons analysé les changements temporels de végétation se produisant le long du Tibre à Nazzano (Rome), comme conséquences de la construction d'un barrage en 1956. Nous avons recherché quelles communautés sont les plus sensibles à cette altération anthropique de l'écosystème de la rivière. Une évaluation de comment et à quel moment ces communautés ont varié leur extension

(1) Department of Sciences, University of Roma Tre, Viale G. Marconi 446, 00146 Rome, Italy

* Corresponding author: ceschin@uniroma3.it 
analyse diachronique, végétation lotique à la suite d'une telle modification est fournie. En outre, le rôle des altérations hydrogéomorphologiques sur l'évolution de la végétation de la rivière, lié à la gestion de ce barrage modifiant les écoulements, a été analysé. Nos résultats montrent les principaux changements de la végétation survenus au cours des premières décennies après la construction du barrage. En fait, le fonctionnement du barrage a provoqué l'expansion locale significative des eaux en amont de la rivière, causant l'inondation de la plupart des terres environnantes, et la création de nouvelles zones humides sub-lentiques. Les conditions hydrogéomorphologiques altérées ont favorisé le développement des communautés ripariennes et des macrophytes naturels typiques des écosystèmes lacustres et donc essentiellement différents de ceux attendus pour la typologie des rivières analysées. Les changements dans l'extension dans le temps de ces communautés végétales mettent en évidence leur relation étroite avec la modification de certains paramètres hydrologiques qui affectent surtout le niveau d'eau de la rivière.

\section{INTRODUCTION}

The damming of a watercourse leads to a wide range of hydrogeomorphic alterations, both in upstream and downstream stretches. The consequences of these alterations on the river ecosystem have been examined especially in downstream stretches in various broader studies concerning dam census and global overview (e.g. Graf, 1999; Nilsson et al., 2005), and review of dam impacts (e.g. Poff et al., 1997; Bunn and Arthington, 2002; Tharme, 2003). Other studies have addressed more specifically the alteration of the aquatic biocoenosis and riparian vegetation in terms of biodiversity (e.g. Townsend et al., 1997; Roy et al., 2005), homogenization (e.g. Cordes et al., 1997; Scott et al., 1997), colonization of invasive species (e.g. Meffe, 1984; Stromberg et al., 2007), habitat availability (e.g. Pasternack et al., 2004; Jacobson and Galat, 2006), and structure of food webs (Wootton et al., 1996).

In the upstream stretch of a river, the main effect of damming is the increased water level and the consequent inundation and loss of habitats of the surrounding riparian areas (Crivelli et al., 1995; Nilsson and Berggren, 2000; New and Xie, 2008). The presence of a dam converts the free-flowing waters of the river into standing waters, creating conditions similar to a lacustrine ecosystem. Such modification causes both the alteration of the natural erosion-transportdeposition processes and the development of new riverbed and riverbank landforms (Nilsson and Jansson, 1995; Jansson et al., 2000a; Evans et al., 2007). These hydrogeomorphic alterations of the river ecosystem strongly affect the structure and distribution of the upstream riparian and aquatic plant communities.

Analyses of the dam impact on the upstream vegetation have become a topic of scientific interest, mainly over the last decades (Nilsson and Berggren, 2000; New and Xie, 2008). Some studies addressed the identification of the main factors affecting the plant colonization of the riverbanks, such as the water level fluctuation (Springuel et al., 1991; Crivelli et al., 1995; Zhang and Lou, 2011) and the instability of the new shorelines (Johnson, 2002). Other studies focused on vegetation differences between river stretches at the reservoirs and those with natural hydrological conditions (Nilsson and Jansson, 1995; Jansson et al., 2000b; Johansson and Nilsson, 2002). Still others compared the riparian vegetation communities of reservoirs with those occurring at run-of-river impoundments, highlighting in some cases less alteration in the run-of-river impoundments (Nilsson et al., 1997), and in others a strong impact, and often indistinct, between the two plant typologies (Jansson et al., 2000a).

In this paper, we analyzed the structure and distribution changes of the vegetation along the Tiber River in Nazzano (Rome) resulting from the construction of a dam in 1956. This dam, which is associable with a run-of-river impoundment according to the our available data, is an interesting case study for the evaluation of alterations due to this type of plant, especially in the Mediterranean region, where the knowledge on this topic is very poor (Crivelli et al., 1995). 


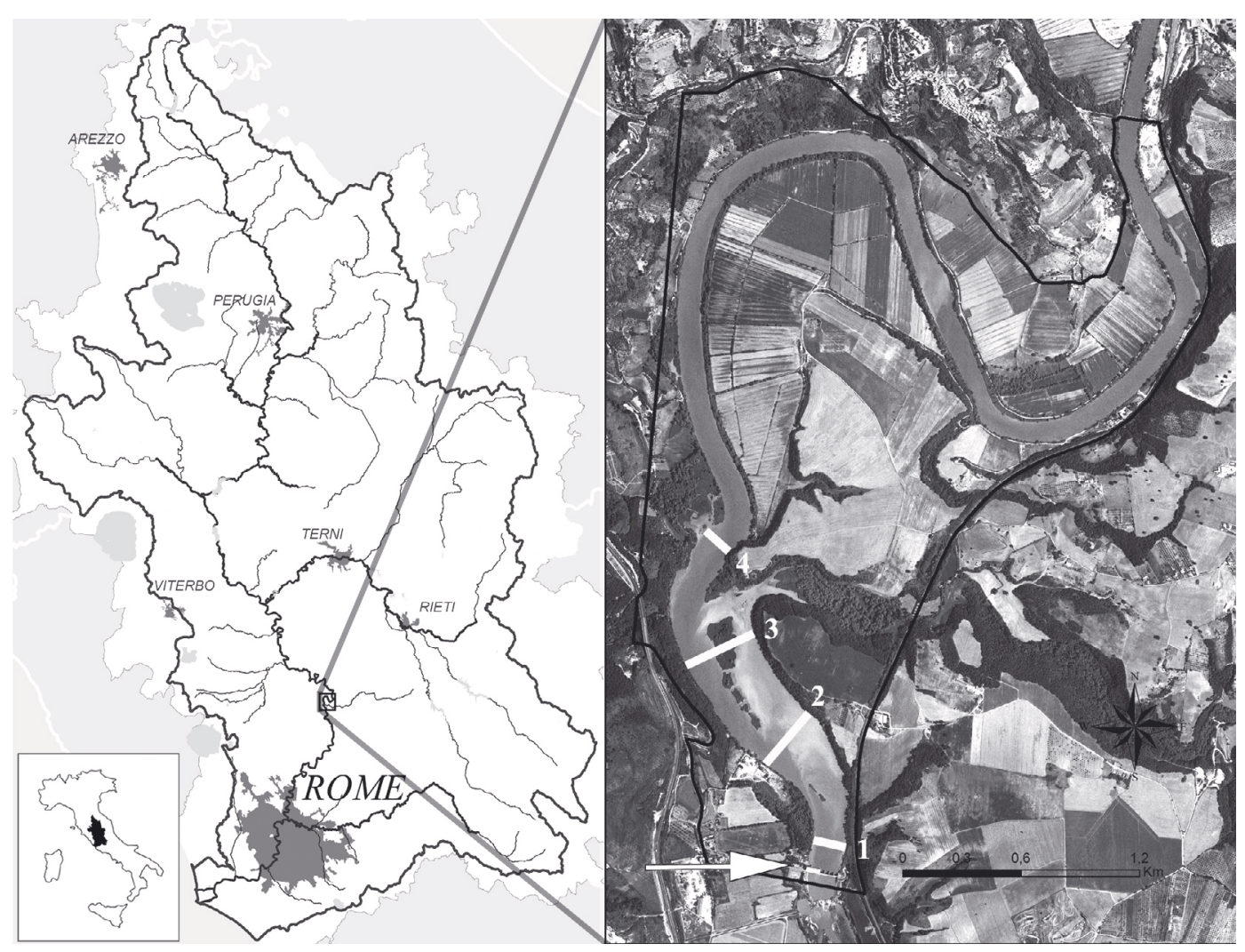

Figure 1

Location of the Tiber-Farfa Regional Natural Reserve in the Tiber River basin. The boundary of the study area, the position of the Nazzano dam (arrow) and the four cross-sections along the Tiber River used to estimate the width of the riverbed, are shown (right).

Although it is known that this dam has contributed to the formation of a new sub-lacustrine ecosystem (the Nazzano Lake), and consequently of new habitats for the development of aquatic and riparian vegetation (AA.VV., 2006; Spada and Casella, 2006; Ceschin and Salerno, 2008), the following specific research questions are still to be answered:

i) Which vegetation types are more sensitive to hydrogeomorphic changes of the river ecosystem caused by the dam construction?

ii) How, and with what timing have these vegetation types varied their extension, as a result of such hydrogeomorphic changes?

iii) What role have the hydrogeomorphic alterations, linked to the management of this dam as a run-of-the-river impoundment, played in the evolution of the river vegetation?

\section{MATERIALS AND METHODS}

\section{> STUDY AREA}

The study area is located along the valley of the lower course of the Tiber River near Nazzano, a village approximately $40 \mathrm{~km}$ North of Rome. The study area is immediately upstream of a hydroelectric dam, the Nazzano dam, built during the years 1953-1955 and operative since 1956. The study area covers a surface of 642 ha, included in the Tiber-Farfa Regional Natural Reserve (Figure 1). The Reserve was founded in 1979 and comprises a Site of Community Importance and a Special Protection Area (IT6030012) (92/43/CEE, 79/409/CEE Directives). The length of the river stretch crossing the study area is $8.5 \mathrm{~km}$ and the storage capacity of the newly-formed Nazzano Lake is about 18 million $\mathrm{m}^{3}$ (AA.VV., 1985). 


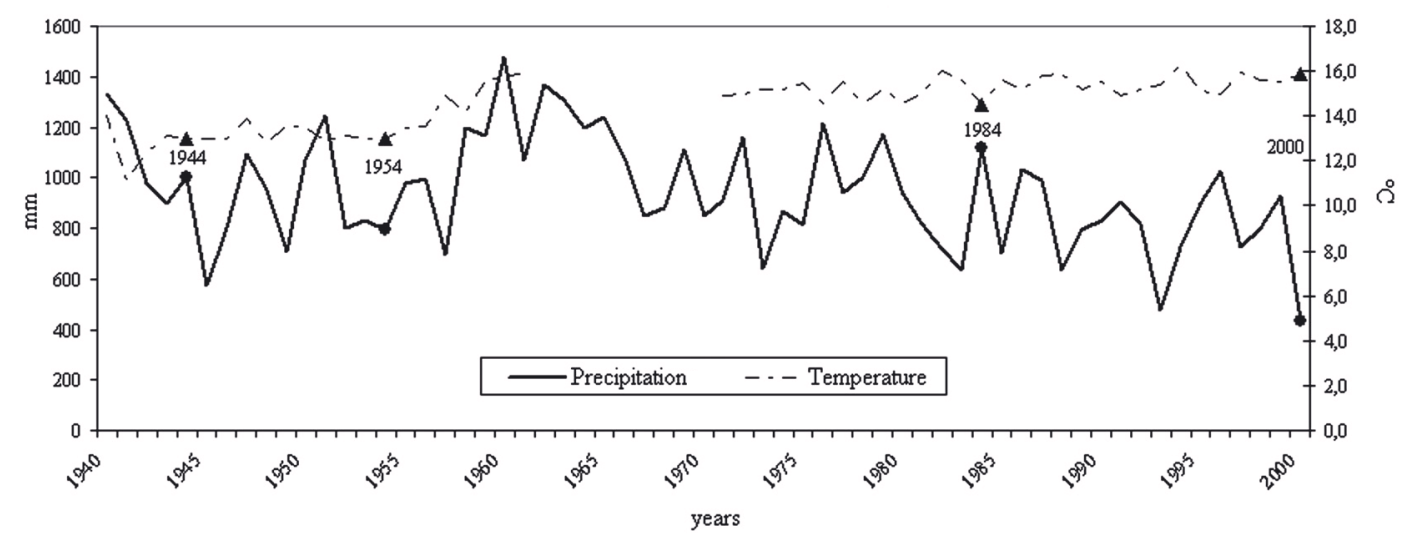

Figure 2

Precipitation and temperature historical records (at Poggio Mirteto weather station) for the period 1940-2000 (data provided by the Hydrographic Office of the Latium Region).

The portion of the Tiber River valley included in the study area is bounded by hills formed by Pleistocene marine sands and conglomerates, and filled by alluvial deposits such as clay, sand and gravel. The elevation of the area ranges between $30 \mathrm{~m}$ a.s.l. at the Nazzano Lake and $202 \mathrm{~m}$ a.s.l. in the village of Nazzano.

From a climatic point of view, the area falls within the Transitional Temperate region, characterized by upper Mesomediterranean thermotype and lower humid ombrotype. It is a semi-arid mesoclimate with an arid period in July and August and a cold stress period that lasts from October to May (Blasi, 1994). Precipitation and temperature historical records (series 1940-2000) are shown in Figure 2. These data refer to the Poggio Mirteto weather station, located $5 \mathrm{~km}$ North of the study area. The pluviometric data show that in 1954 the precipitation was lower than that recorded in 1944. In addition, the combined thermo-pluviometric data show that a dry period occurred from 1981 to 2000 , due to the reduced precipitation and the increased temperatures.

From a hydrological point of view, in Nazzano Lake the monthly variability of the water level is kept low by the maintenance of the reservoir water level at the spillway crest elevation during the whole year (Figure 3). At the analyzed river stretch, the average estimated flow is $189 \mathrm{~m}^{3} \cdot \mathrm{s}^{-1}$ (Gallo, 1983). Upstream and downstream with respect to the Nazzano dam, the flow regime is substantially similar, as evidenced by the comparison of the water flows measured at the Ponte Felice gauge (1968-1971, unique data available; about $40 \mathrm{~km}$ upstream of the dam) and Ripetta gauge (1968-1971; about $50 \mathrm{~km}$ downstream of the dam) (Figures 4 and 5). These data on the water flows were compared using the trend of the Flow Duration Curves (graphical representation of a ranking of all the flows in a given period) (Figure 4) and some of hydrological parameters included in the Indicators of Hydrologic Alteration (IHA) (Richter et al., 1996; The Nature Conservancy, 2009), such as the Base Flow Index (7-day minimum flow/mean flow for year), the Julian Day of Minimum Flow, and the Number of Reversals (the number of times the flow switches from a rising to a falling period or vice versa) (Figure 5).

The Nazzano dam has a limited capacity to modify the water flow since it does not significantly alter the hydrological regime either in the upstream or downstream stretches. The capacity of the reservoir (18 million $\mathrm{m}^{3}$ ) represents a small fraction of the annual average runoff (about 5.9 billion $\mathrm{m}^{3}$ ) and allows regulation only on a daily scale. On the basis of these findings the Nazzano Lake can be regarded as a run-of-the-river impoundment. In addition, for the considered time period, the historical series of the Tiber River flows from 1940 to 2000, recorded at the Ripetta gauge, can be regarded as adequately representative of the temporal trend of the water flow occurring at the investigated Tiber River stretch (Figure 6). 


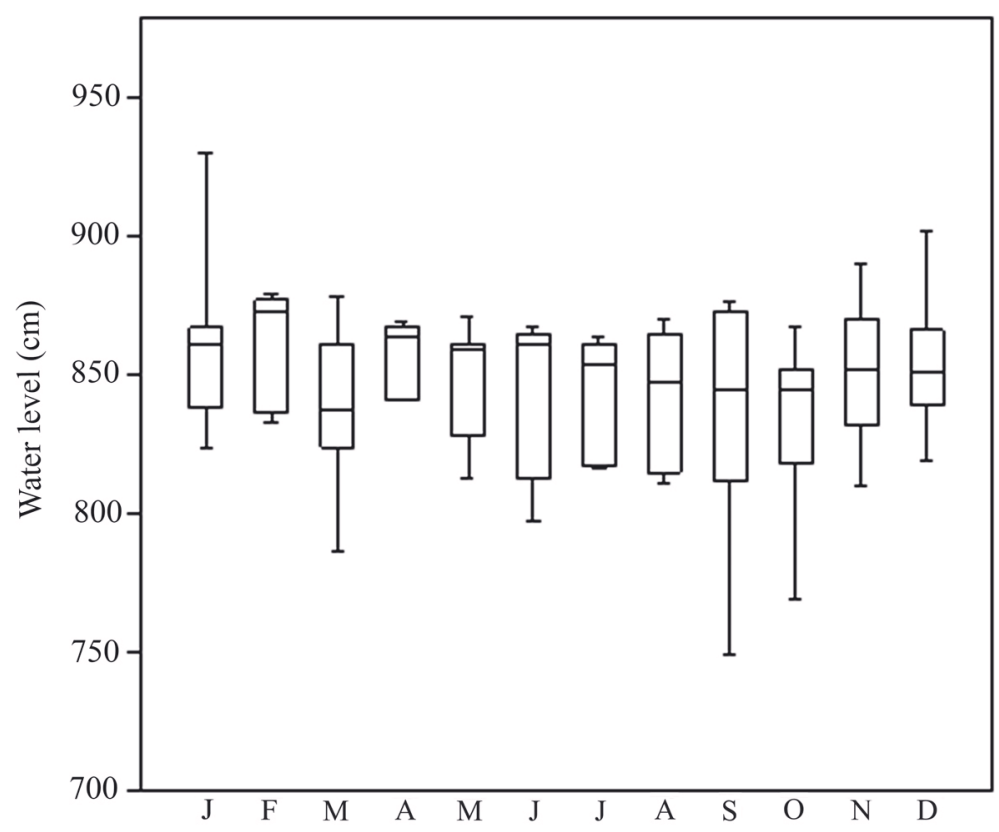

Figure 3

Monthly variation of the water level in Nazzano Lake in the years 1994-1999 (data provided by the Hydrographic Office of the Latium Region).

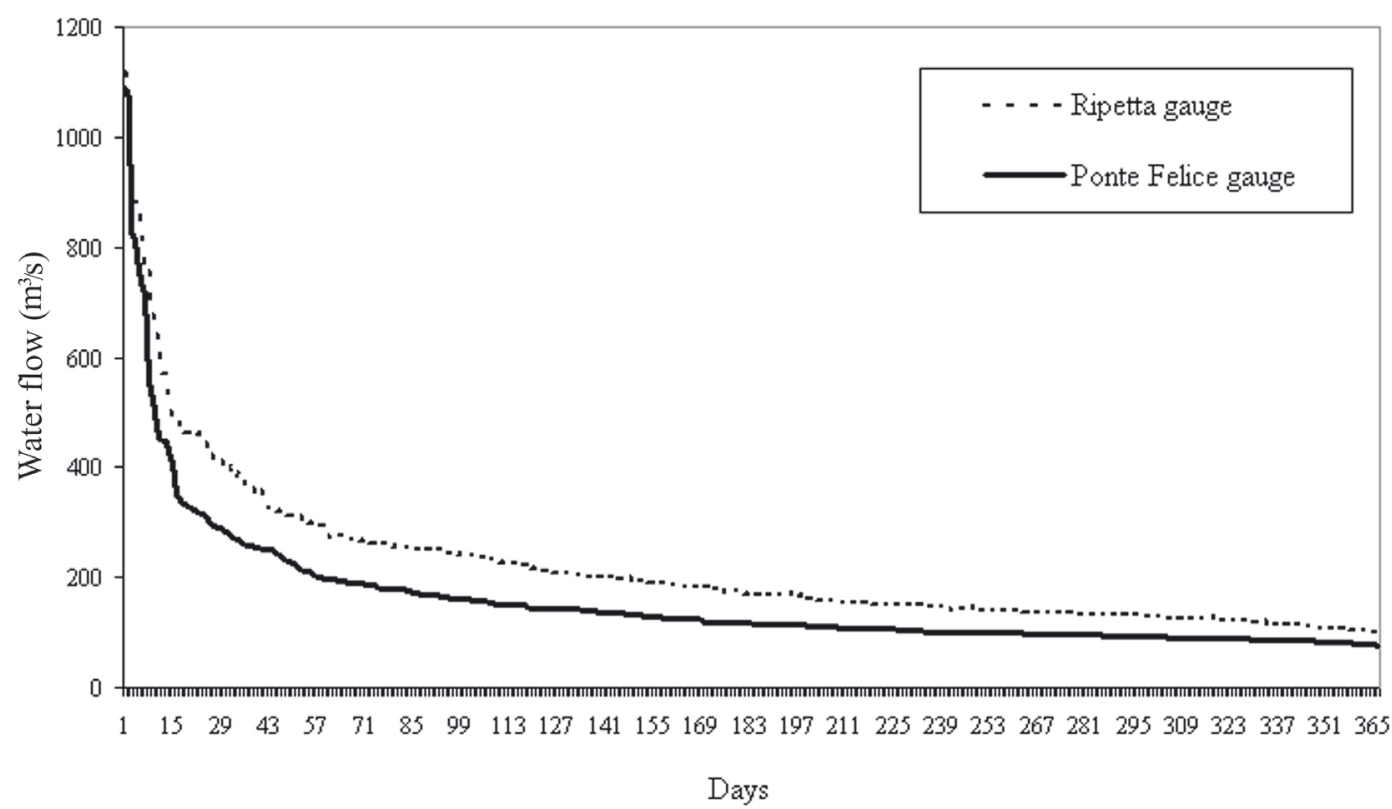

Figure 4

Comparison between daily water flows (Flow Duration Curves) at Ponte Felice gauge (upstream of the dam) and Ripetta gauge (downstream) in the years 1968-1971 (data provided by the Hydrographic Office of the Latium Region).

\section{> DATA COLLECTION AND MAPPING}

For the diachronic analysis of the vegetation and some geomorphic characteristics, we used a set of aerial photos taken during the summer season from 1944, 1954, 1984 and 2000, corresponding to the periods before (1944), during (1954) and after the dam construction (1984, 2000). 
Base Flow Index

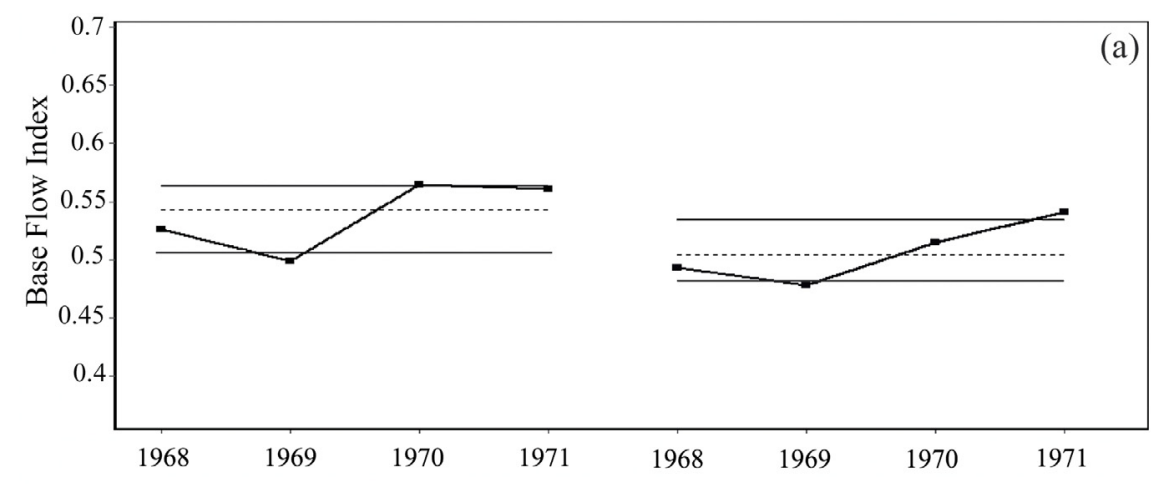

Minimum Flow

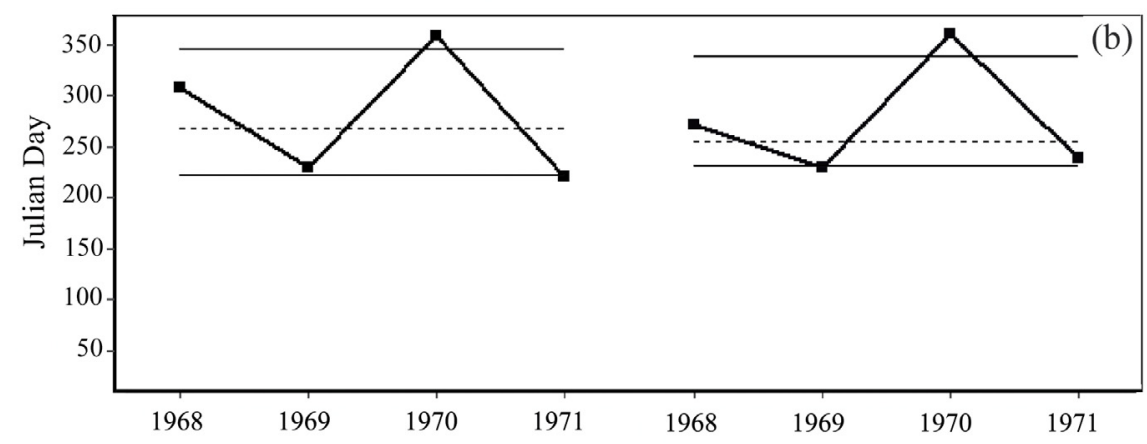

Reversals

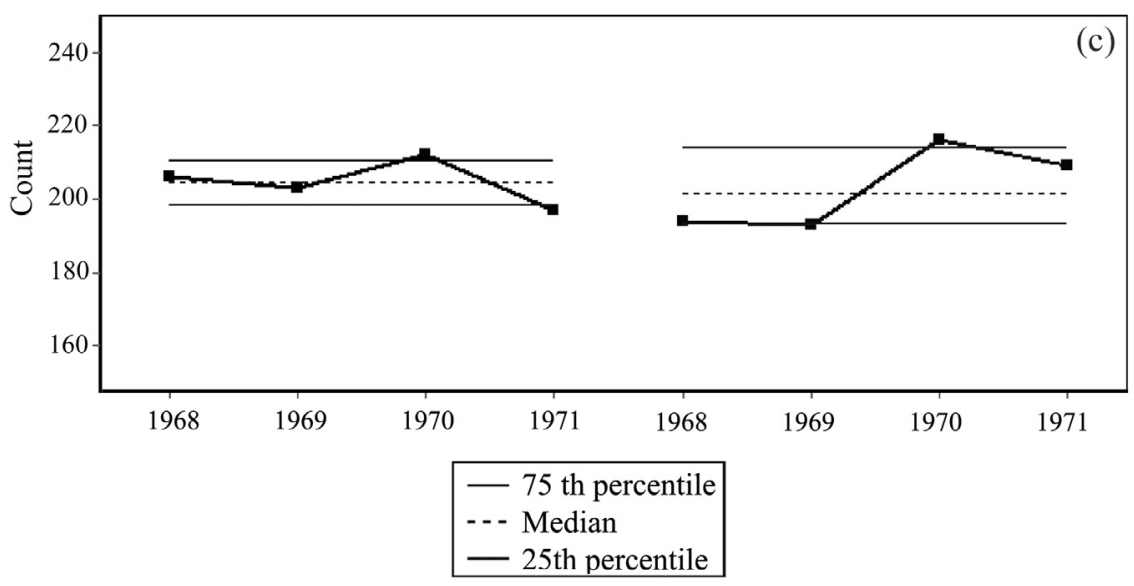

\section{Figure 5}

Comparison of water flow data recorded at Ponte Felice gauge (upstream of the dam) (on the left) and Ripetta gauge (downstream) (on the right) in the years 1968-1971, utilizing the Base Flow Index (a), Julian day of Minimum Flow (b), and Number of Reversals (c) (data provided by the Hydrographic Office of the Latium Region).

In order to evaluate the geomorphic changes over the considered time period, on the four aerial photos we measured the width of the riverbed in four equally spaced cross-sections (about $570 \mathrm{~m}$ ) located along the river stretch (see Figure 1). We also calculated the Sinuosity Index (distance covered by the meander / straight line distance covered by the meander), in order to evaluate the riverbed typology and its eventual evolution during the considered time period.

As regards the vegetation analysis, we firstly digitalized the vegetation in the aerial photos and analyzed the data with ArcGis 9.0 (ESRI Inc., Redland, CA). The different vegetation 


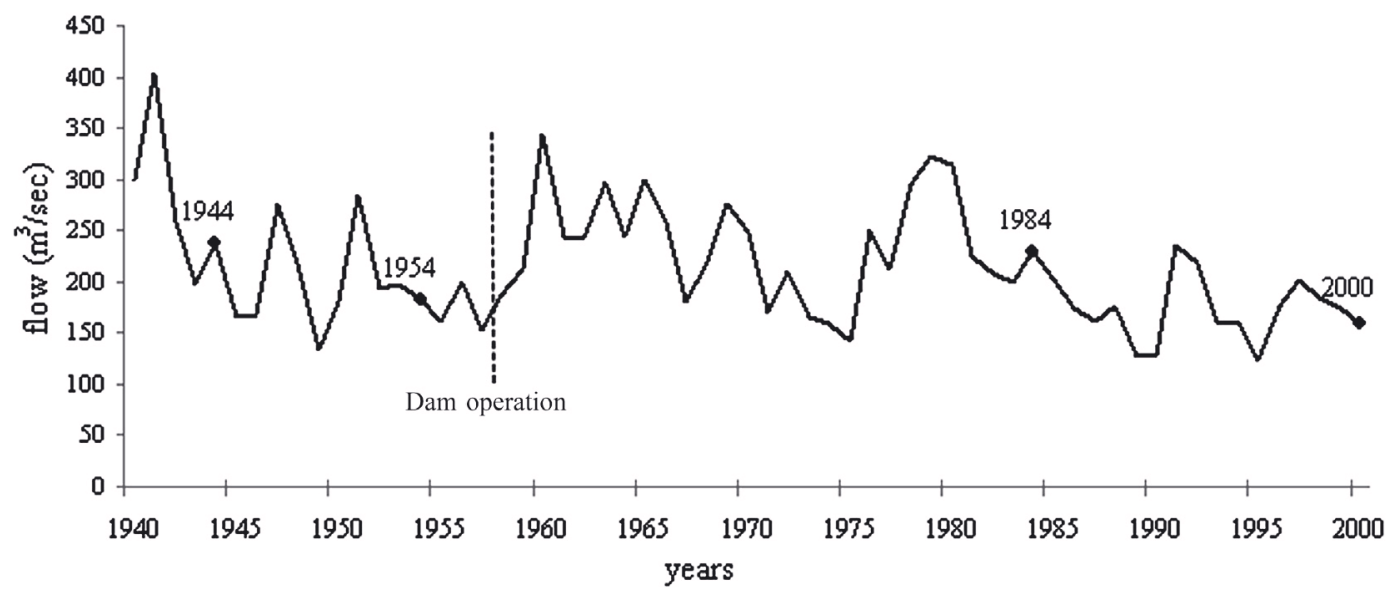

\section{Figure 6}

Tiber River flows (at Ripetta gauge) for the period 1940-2000 (data provided by the Hydrographic Office of the Latium Region).

types were mapped on an approximate scale of 1:10.000. On this scale, it was possible to distinguish eight land cover categories referring to spontaneous vegetation and belonging to woody, shrubby, and herbaceous communities (Table I).

Subsequently, the mapped vegetation types were verified in field through 18 vegetation surveys during the period June-September 2010 using the phytosociological method of Braun-Blanquet (1932). In addition, vegetation surveys available in literature on the study area (D'Antoni et al., 2002; Spada, 2006; Spada and Casella, 2006; Fanelli et al., 2007; Ceschin and Salerno, 2008) were utilized.

Finally, the characterization of the vegetation types through phytosociological surveys allowed to assign a land cover category to each recognized vegetation type. We used the Corine Land Cover Legend (APAT, 2005; Sambucini et al., 2010), according to ISPRA (2010) for the fourth level of detail. In addition, we defined a new land cover category (coded 4.1.3) specifically to describe the macrophyte vegetation (see Table I).

To analyze the vegetation temporal patterns over the 1944-2000 period, we used a chronosequence approach. We compared the four obtained land cover maps and quantified the temporal variations in extension of the different vegetation types.

\section{RESULTS}

The outcomes of the diachronic analysis of the riverbed amplitude clearly distinguish the pre- and post-dam periods (Figure 7). In the pre-dam period (1944-1954) the riverbed width remained substantially unchanged, while in the post-dam period (1954-1984) it increased significantly. In particular, in the sections 2 and 3, the riverbed became respectively 7 and 6 times larger than the previous period. In the last period (1984-2000), values very similar to those measured in the 1954-1984 period are recorded in all four sections. The value of the Sinuosity Index is approximately equal to 2 , describing a meandering riverbed (Thorne, 1997). This value remained substantially unchanged for all dates considered.

The land cover categories that showed the most significant changes in extension are: Inland waters, Macrophyte vegetation, Broad-leaved forests with prevalence of hygrophilous species, Natural grasslands, Arable land, Moors and heathland, and Open spaces with little or no vegetation (see Table I).

The first five land cover categories listed above are those more widespread in the study area and mostly influenced by the dam effect, being closer to the river. Their extension changes occurring during the considered chronosequence are shown in Figure 8. 


\begin{tabular}{|c|c|c|c|c|c|c|c|c|c|}
\hline 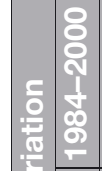 & ○ & 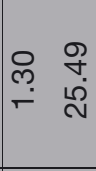 & 竎 & $\begin{array}{l}\mathscr{8} \\
\stackrel{0}{1} \\
\stackrel{1}{1}\end{array}$ & $\begin{array}{l}\frac{5}{i n} \\
\stackrel{\sim}{1}\end{array}$ & $\begin{array}{l}\text { ले } \\
\text { ळె }\end{array}$ & 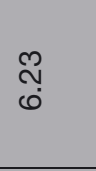 & $\begin{array}{l}\dot{0} \\
\infty \\
\infty\end{array}$ & $\begin{array}{l}\infty \\
\infty \\
\stackrel{1}{1} \\
\text { † }\end{array}$ \\
\hline 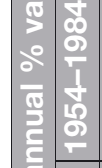 & ○ & $\begin{array}{ll}0 & 0 \\
0 & 0 \\
0 & 0 \\
1 & 1 \\
1 & 1\end{array}$ & 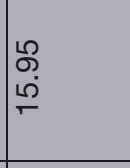 & $\begin{array}{l}\stackrel{N}{\sigma} \\
\stackrel{6}{\sigma}\end{array}$ & $\stackrel{\stackrel{\sim}{N}}{\bar{\varphi}}$ & 1 & $\begin{array}{l}\hat{\infty} \\
\stackrel{\infty}{+} \\
\stackrel{T}{1}\end{array}$ & $\begin{array}{l}\stackrel{L}{0} \\
\infty \\
\infty \\
\infty\end{array}$ & $\begin{array}{l}\hat{N} \\
\tilde{m}\end{array}$ \\
\hline 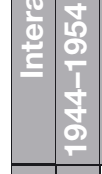 & \begin{tabular}{l}
$\infty$ \\
\multirow{0}{*}{} \\
$\dot{\omega}$
\end{tabular} & 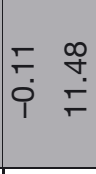 & $\frac{10}{10}$ & $\begin{array}{l}\widetilde{N} \\
o{ }^{\circ} \\
0\end{array}$ & $\stackrel{\simeq}{\leftarrow 0}$ & 1 & $\begin{array}{l}\stackrel{\infty}{0} \\
\stackrel{p}{p}\end{array}$ & ๗ָ & $\begin{array}{l}\hat{\infty} \\
\dot{\omega} \\
\stackrel{N}{0}\end{array}$ \\
\hline \multirow{2}{*}{ 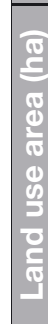 } & 을 & 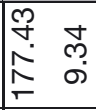 & $\stackrel{\hat{s}}{\hat{s}}$ & $\begin{array}{l}\text { ల్ } \\
\text { ळె } \\
\end{array}$ & $\begin{array}{l}\hat{N} \\
\text { in } \\
\text { م. }\end{array}$ & $\stackrel{\Gamma}{r}$ & $\begin{array}{l}\stackrel{+}{\text { }} \\
\stackrel{m}{m} \\
\stackrel{5}{-}\end{array}$ & $\frac{\llcorner}{\stackrel{\sim}{N}}$ & $\stackrel{\simeq}{\check{r}}$ \\
\hline & 永 & 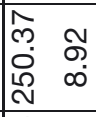 & $\stackrel{?}{\stackrel{9}{-}}$ & $\begin{array}{l}\infty \\
\stackrel{\infty}{\infty} \\
\infty \\
\infty\end{array}$ & $\begin{array}{l}\text { जे } \\
\text { लें } \\
\end{array}$ & 1 & 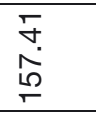 & $\begin{array}{l}8 \\
0 \\
0\end{array}$ & $\stackrel{\text { テ }}{\leftarrow}$ \\
\hline 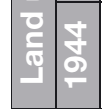 & \begin{tabular}{l}
$\infty$ \\
$\infty$ \\
$\infty$ \\
\hdashline \\
\end{tabular} & 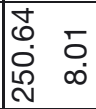 & 范 & $\begin{array}{l}\frac{0}{\dot{v}} \\
\stackrel{\gamma}{f}\end{array}$ & 占 & 1 & 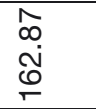 & $\begin{array}{l}\text { Lे } \\
0\end{array}$ & $\stackrel{N}{\longleftarrow}$ \\
\hline 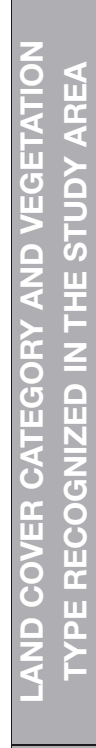 & 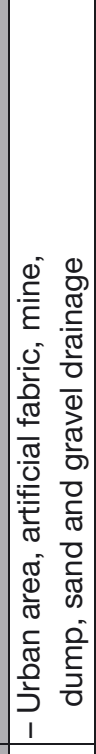 & 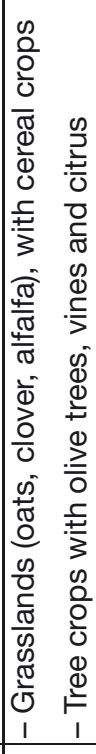 & 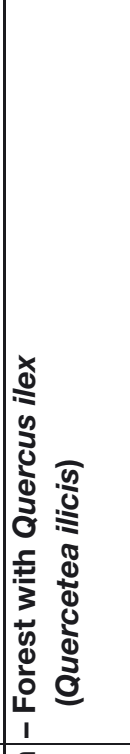 & 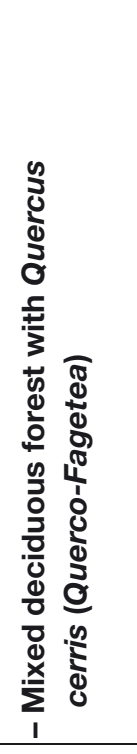 & 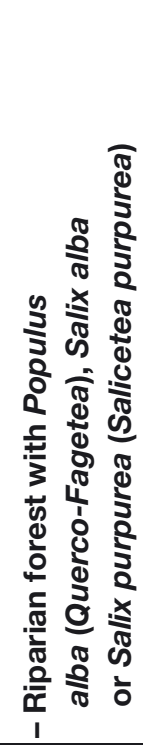 & 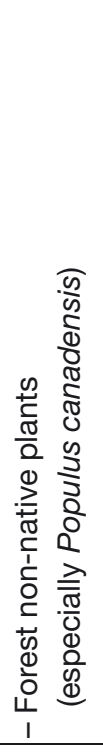 & 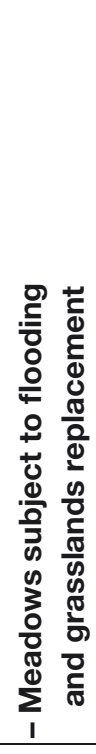 & 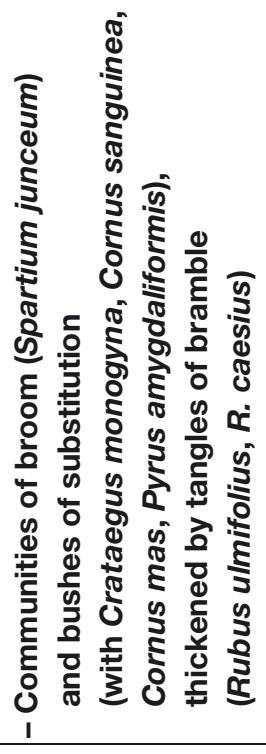 & 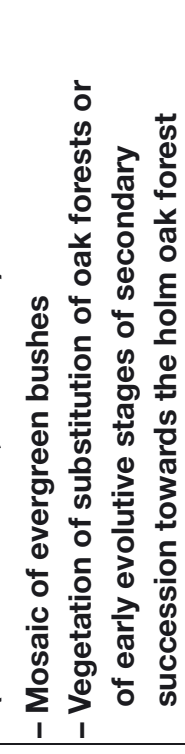 \\
\hline \multirow{2}{*}{ 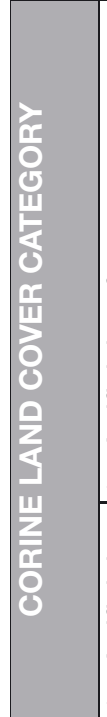 } & 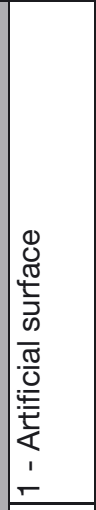 & 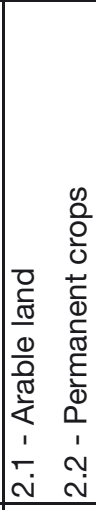 & 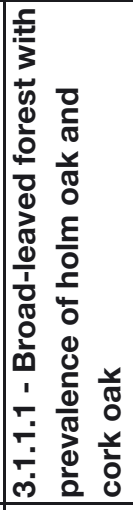 & 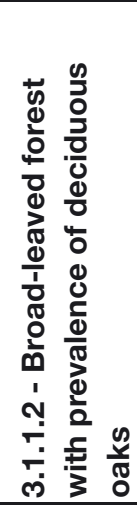 & 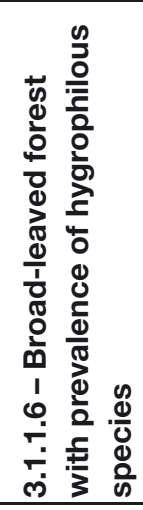 & 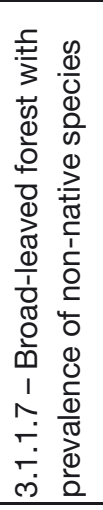 & 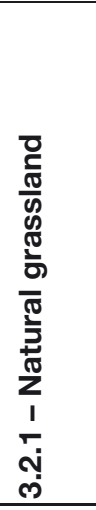 & 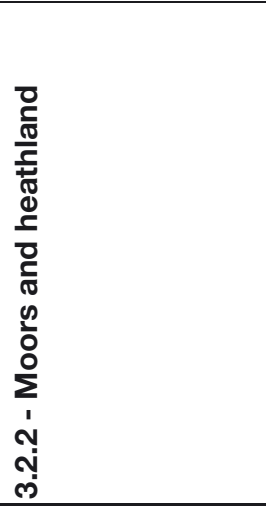 & 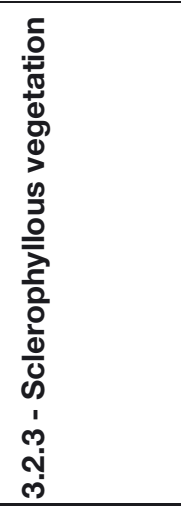 \\
\hline & 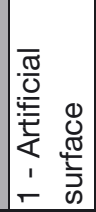 & 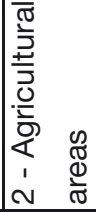 & 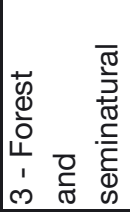 & 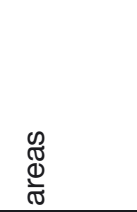 & & & & & \\
\hline
\end{tabular}




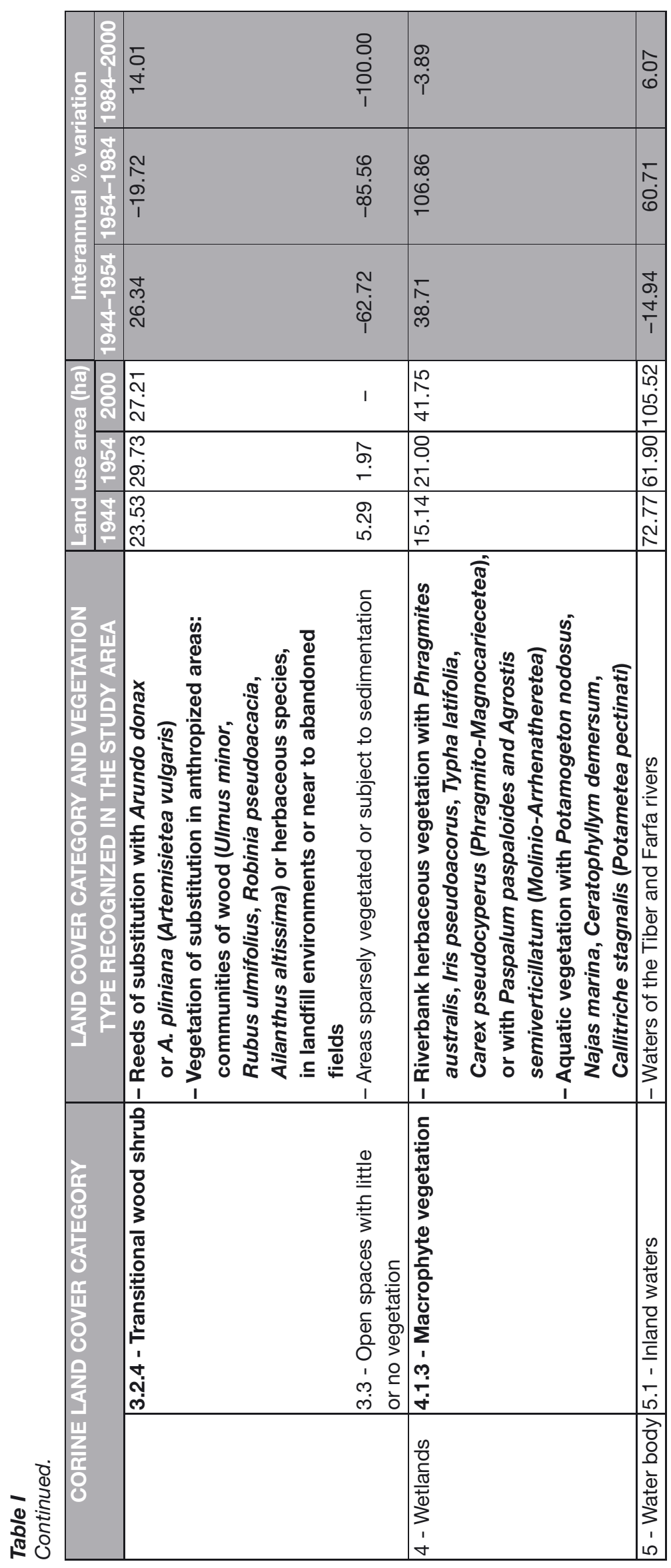




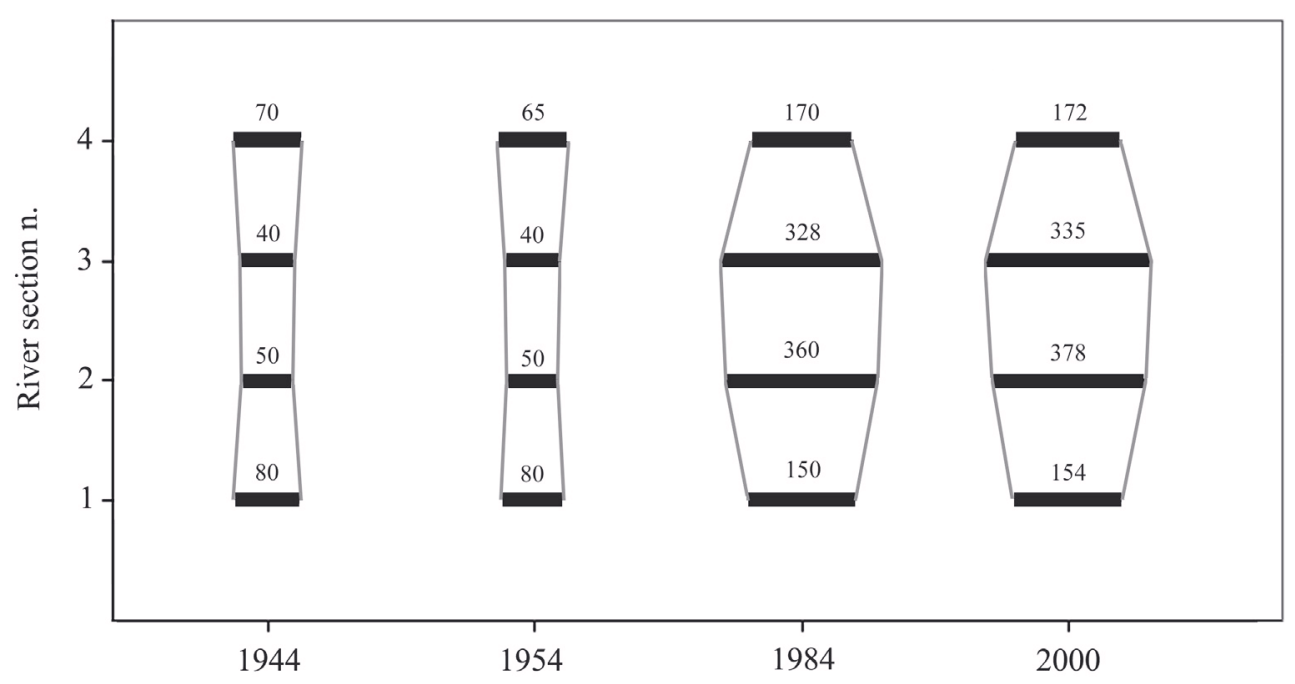

\section{Figure 7}

Diachronic analysis of the riverbed width (in meters) variation in the four river sections identified along the Tiber River.

In the period 1944-1954, before the dam was constructed, we observed a decrease of $15 \%$ in the surface occupied by Inland waters and a first expansion of the Macrophyte vegetation $(+38.71 \%)$, especially near the confluence of the Farfa into the Tiber River. Also, the Open spaces with little or no vegetation greatly changed and decreased by over $60 \%$.

During the subsequent period 1954-1984, after the dam came into operation, the area occupied by Inland waters greatly increased $(+60.71 \%)$, with consequential lateral expansion of the river waters, while the Arable land decreased by more than $30 \%$, as a result of its partial flooding. The Macrophyte vegetation greatly expanded $(+106.89 \%)$, as well as the Broadleaved hygrophilous forests (+61.25\%). Instead, the areas covered by the Natural grasslands decreased in extension $(-17.87 \%)$.

Between 1984 and 2000 the extension changes of the different land cover categories were less evident than in the previous period. However, among the main findings occurred during this period, we highlight a further increase in the Inland waters (+6.07\%), and a general stabilization of the Macrophyte vegetation.

\section{DISCUSSION}

Through aerial photo digitization and interpretation, we could highlight the temporal dynamics of the land cover categories mainly influenced by the dam operation. We observed contraction in the extension of certain categories and local disruption of others, as well as some cases of meaningful expansion.

Comparing the 1954 situation with that of 1944, it is clear that the changes in extension of the land cover categories cannot be related to the dam, which became operative in 1956. Particularly, the decrease in the surface covered by Inland waters could be mainly linked to the lower rainfall (see Figure 2), and therefore to the 1954 river flows being lower than those of 1944, as recorded in the downstream Tiber stretch (Figure 6). Consequently, the probable reduction of the river level in the pre-dam period, as well as of the water velocity, could explain the observed increase in the surface occupied by the Macrophyte vegetation, especially on the riverbanks.

After the water level stabilized as a result of the dam operation, there was a significant expansion of the Inland waters and a reduction in the extension of the Arable land subject to flooding. The areas covered by Natural grasslands, previously subject to periodic flooding and then, after the dam construction, drained by networks of channels for agricultural purposes (Regione Lazio, 2007), were significantly reduced. 

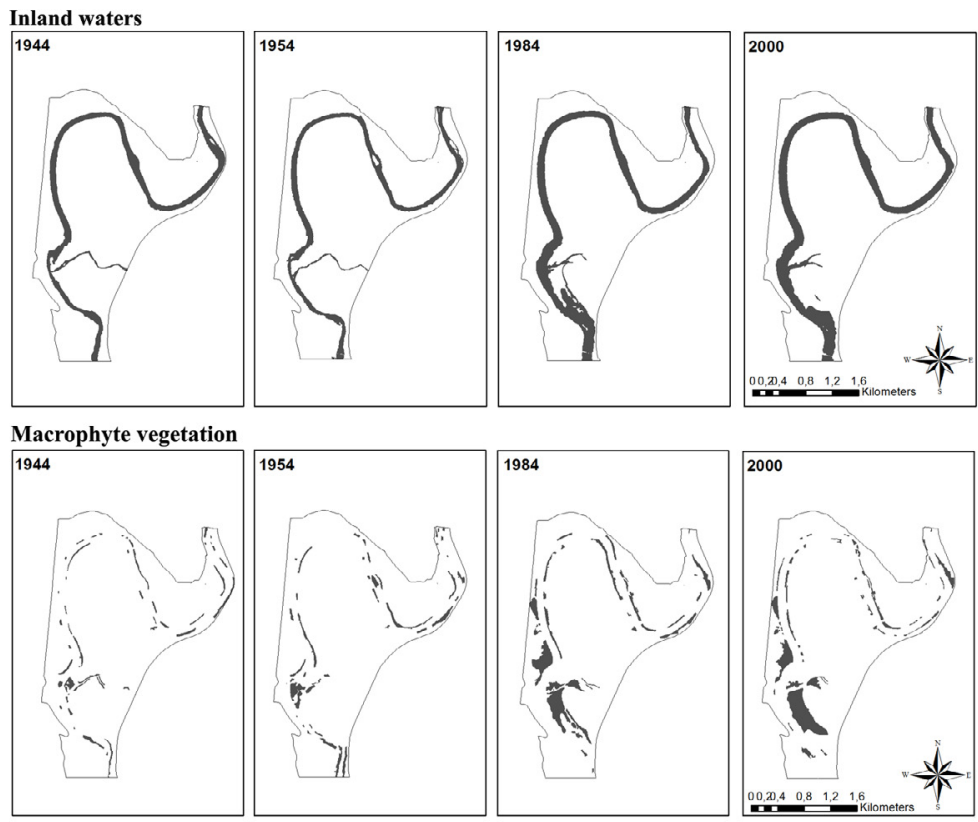

Broad-leaved forests with prevalence of hygrophilous species
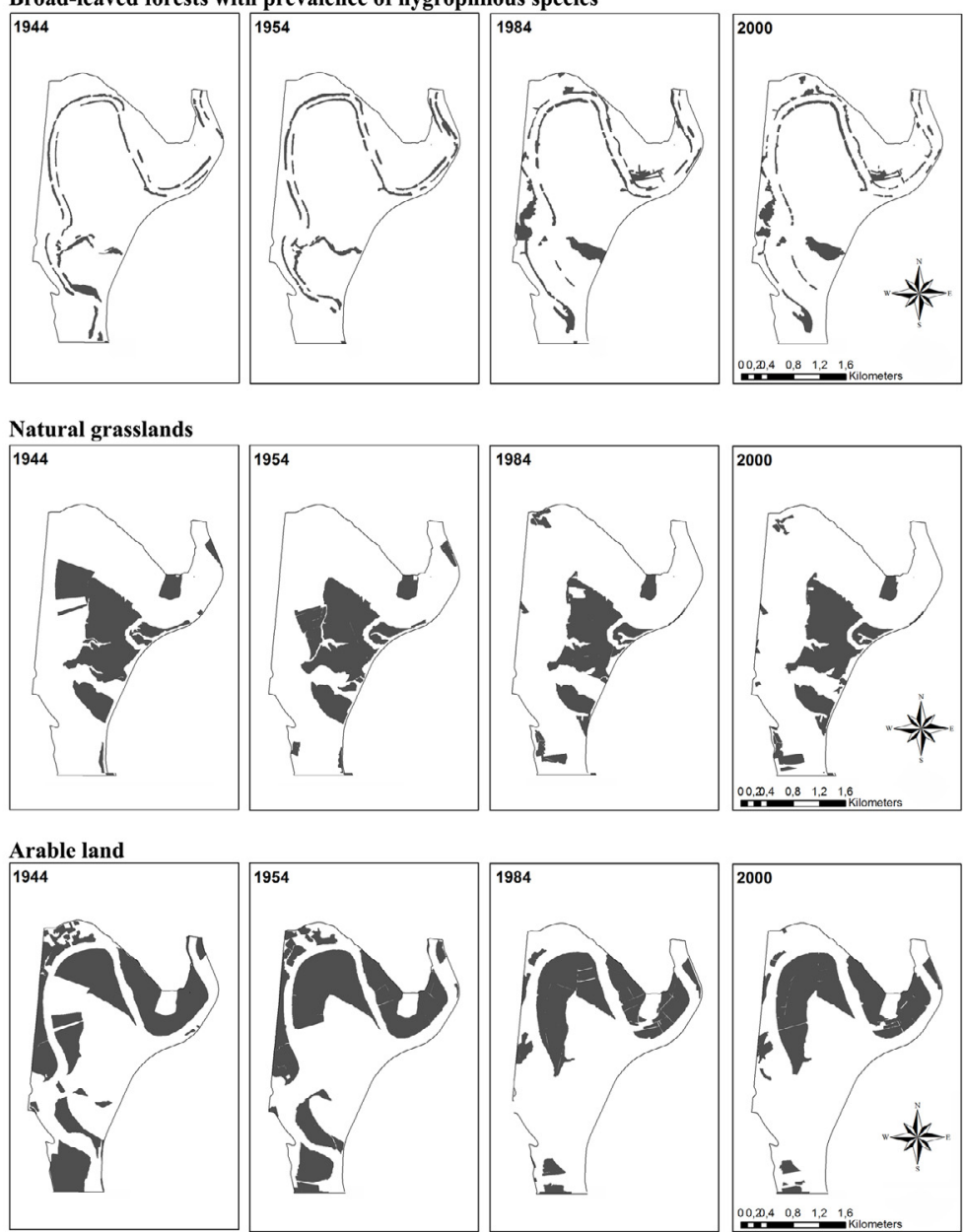

Figure 8

Changes occurring over the 1944-2000 period in the land cover categories closer to the river and more widespread in the study area are reported (Inland waters, Macrophyte vegetation, Broad-leaved forests with prevalence of hygrophilous species, Natural grasslands and Arable land). 
In the 1954-1984 period, as a consequence of the water level stabilization and the expansion of the riverbed linked to the dam operation, the Macrophyte vegetation greatly increased, since new areas for the colonization of helophytes and hydrophytes occurred. Indeed, aquatic communities of the Potametea pectinati class, such as Myriophylletum verticillati, Ceratophylletum demersi, Potametum nodosi and Najadetum marinae, usually recorded in lacustrine environments or in almost standing waters (e.g. Pedrotti and Orsomando, 1982; Iberite et al., 1995; Venanzoni et al., 2003; Venanzoni and Gigante, 2000; Minissale and Spampinato, 1985), began to develop in the newly-formed waterbody and then spread in most parts of the area over time. The new sub-lacustrine habitat also favored the development of riverbank macrophyte communities of the Phragmito-Magnocaricetea class, such as Phragmitetum vulgaris, Iridetum pseudacori, Typhetum latifoliae and Mentho-Caricetum pseudocyperi. These communities are adapted to long periods of submersion and to slow-flowing waters.

Near the riverbanks, where sediments naturally deposit because of the water velocity reduction, the Broad-leaved hygrophilous riparian forests with Salix alba and Populus alba do not keep a pioneer shrubby character, such as under typical dynamic river conditions (Fenner et al., 1985; Johnson, 1999), but grow in dense and mature formations.

The changes in extension of the Macrophyte vegetation and Broad-leaved hygrophilous riparian forests highlight the close correlation between these vegetation types and the alteration of some hydrological parameters especially affecting the water level; this finding generally confirms the results of other investigations (Jansson et al., 2000a; Johansson and Nilsson, 2002).

Some case studies report that strong variations in water level, in terms of frequency, magnitude and timing, give rise to significant changes in phytomass and plant biodiversity (Johansson and Nilsson, 2002; Johnson, 2002; Ali, 2006; Zhang and Lou, 2011; Krolová et al., 2013). In other studies the formation of new habitats and significant changes in the vegetation types as a consequence of alterations in river water level, were observed (Crivelli et al., 1995; Springuel et al., 1997). Our study, in accordance with the latest investigations, shows how the dam construction has implied the formation of a new lacustrine habitat that has created optimal ecological conditions for the growth of various aquatic plant communities. Most of them are typical of lentic habitats, such as Najadetum marinae, Callitrichetum stagnalis, Ceratophylletum demersi and Iridetum pseudacori. Therefore they differ in structure and species composition from those occurring in the other portions of the Tiber River with typical running waters. Data from specific studies on the vegetation of the Tiber River (Ceschin and Salerno, 2008; Ceschin et al., 2010a, 2010b) confirm that these aquatic communities, currently found in the study area, were not recorded or were only sporadically recorded in the other stretches of the Tiber lower course, not finding suitable ecological conditions for colonization.

The novel sub-lentic habitat formed in the area as a consequence of the anthropogenic action of dam construction, is similar to a natural lake habitat. This is related to the type of anthropic management of the water resource, which affects the water level changes. Indeed, the Nazzano Lake is a run-of-the-river impoundment, characterized by fluctuations of the water level with a seasonal pattern similar to the natural one. In many other storage reservoirs, the altered hydrological conditions are so different from any natural pattern that no plant has adaptations to survive them (Jansson et al., 2000a; Johnson, 2002; Zhang and Lou, 2011). The Nazzano dam has allowed the development of novel semi-natural water habitats that were colonized by riparian and macrophyte communities of great naturalistic and conservation interest. The plant colonization has been relatively quick in the study area, as can be observed by the diachronic vegetation maps (Figure 8). This speed is due in part to the colonization of new communities adapted to perennially flooded environments, and in part to the resilience of the communities occurring in the pre-dam ecosystem, as described in other case studies (Nilsson et al., 1997). 


\section{CONCLUSIONS}

Considering the local transformations of the Tiber River landscape over time, after the construction of the Nazzano dam, we can state that the resulting hydrogeomorphic processes are determinants for the structure and distribution of vegetation types along the river. Taking into account the specific research questions of this study, the macrophyte and woody hygrophilous riparian communities represent the vegetation types more sensitive to the hydrogeomorphic changes occurring over time. In fact, these communities began to greatly expand in the period immediately after the dam construction. After about thirty years, they have reached a certain stabilization, due both to the general hydrogeomorphic stability in the area and the conservation policy adopted by the Reserve, limiting land use changes in the area.

One of the direct effects of the Nazzano dam operation has been the flooding of the upstream surrounding lands. One of the indirect effects has been the formation of a sub-lacustrine habitat. This new habitat, characterized by slow-flowing waters, has provided suitable conditions for the development of a rich hydrophyte and helophyte vegetation and extended woody riparian communities, as well as the colonization of several animals adapted to life in semiaquatic conditions, particularly aquatic birds. The great potential of this man-made wetland from a naturalistic and landscape point of view, and the consequent need to protect it, were confirmed in 1979 (L.R. 21/1979) by the institution of the Tiber-Farfa Natural Regional Reserve according to the Ramsar Convention on wetlands of international importance.

The described ecosystem's condition is closely linked to the type of water resource management, which in the case of the Nazzano dam, an example of a run-of-the-river impoundment, simulates hydrogeomorphic conditions little different from those occurring in natural lacustrine environments.

However, the altered hydrogeomorphic conditions caused by the dam construction have led to the formation of vegetation communities different in structure and composition than those expected for the analyzed river typology, thereby altering the ecological status of the river ecosystem.

In order to confirm the conclusions emerging from this study, further investigations should be carried out on the relationship between the management typologies of the run-of-the-river impoundment and the response of the upstream riparian and aquatic vegetation, with the ultimate goal of contributing to the definition of a management model of more sustainable water resources from an ecological point of view.

\section{ACKNOWLEDGEMENTS}

The authors wish to thank the staff of the "Museo del Fiume" in Nazzano, especially the director Umberto Pessolano for his suggestions in the phase of data collection. We are grateful to the Reserve staff and park keepers for their hospitality and their help during fieldwork. Also we thank Dr. Ilaria Mazzini for a linguistic review of this manuscript, and the anonymous reviewers for their revision work, that allowed the improvement of this manuscript.

\section{REFERENCES}

AA. VV., 1985. II Tevere Natura, storia e territorio da Nazzano a Castel Giubileo, Savelli Editore, Roma, $155 \mathrm{p}$.

AA.VV., 2006. SIC-ZPS IT 6030012 "Riserva Naturale Tevere Farfa". Sintesi del piano di gestione, Arpinate Stampa S.R.L., Arpino (FR), 39 p.

Ali M.M., 2006. Shoreline vegetation of Lake Nubia, Sudan. Hydrobiologia, 570, 101-105.

APAT, 2005. La realizzazione in Italia del progetto europeo Corine Land Cover 2000. Rapporti APAT, 36, Roma, 1-86 p.

Blasi C., 1994. Fitoclimatologia del Lazio. Fitosociologia, 27, 151-175. 
Braun-Blanquet J., 1932. Plant sociology: the study of plant communities, McGraw-Hill, New York, $439 \mathrm{p}$.

Bunn S.E. and Arthington A.H., 2002. Basic principles and ecological consequences of altered flow regimes for aquatic biodiversity. Environ. Manage., 30, 492-507.

Ceschin S. and Salerno G., 2008. La vegetazione del basso corso del Fiume Tevere e dei suoi affluenti (Lazio, Italia). Fitosociologia, 45, 39-74.

Ceschin S., Salerno G., Bisceglie S. and Kumbaric A., 2010. Temporal floristic variations as indicator of environmental changes in the Tiber River in Rome. Aquat. Ecol., 44, 93-100.

Ceschin S., Zuccarello V. and Caneva G., 2010b. Role of macrophyte communities as bioindicators of water quality: application on the Tiber River basin (Italy). Plant. Biosyst., 144, 528-536.

Cordes L.D., Hughes F.M.R. and Getty M., 1997. Factors affecting the regeneration and distribution of riparian woodlands along a northern prairie river: The Red Deer River, Alberta, Canada. J. Biogeogr., 24, 675-695.

Crivelli A.J., Grillas P. and Lacaze B., 1995. Responses of vegetation to a rise in water level at Kerkini Reservoir (1982-1991), a Ramsar site in Northern Greece. Environ Manage, 19, 417-430.

D'Antoni S., Pacini A., Cocchieri G., Pittiglio C. and Reggiani G., 2002. L'impatto della nutria (Myocastor coypus) nella Riserva Naturale Tevere-Farfa (RM). Atti Conv. Naz. La gestione delle specie alloctone in Italia: il caso della nutria e del gambero rosso della Louisiana - Firenze, 24-25 September 2002, 35-38.

Evans, J.E., J.M. Huxley and R.K., 2007. Vincent, upstream channel changes following dam construction and removal using a GIS/remote sensing approach. J. Am. Water. Res. Assoc., 43, 683-697.

Fanelli G., Bianco P.M., Cazzagon P., D’Angeli D., De Sanctis M., Bertarelli M., Caroselli V., De Corso S., Gioia P., Guerra A., Serafini Sauli A., Testi A. and Pignatti S., 2007. Banche dati vegetazionali della Provincia di Roma. Memoria illustrativa della carta della vegetazione della Provincia di Roma, Assessorato alle Politiche del Territorio, Roma, $128 \mathrm{p}$.

Fenner P., Brady W.W. and Patton D.R., 1985. Effects of regulated water flows on regeneration of Fremont cottonwood. J. Range Management, 38, 135-138.

Gallo M., 1983. La riserva naturale Nazzano-Tevere-Farfa (The Nazzano-Tiber-Farfa Nature Reserve). II Comune democratico, 2, 73-78, Edizione delle Autonomie, Roma.

Graf W.L., 1999. Dam nation: A geographic census of American dams and their large-scale hydrologic impacts. Wat. Resour. Res., 35, 1305-1311.

Iberite M., Palozzi A.M. and Resini A.M., 1995. La vegetazione del Lago di Bolsena (Viterbo, Italia centrale). Fitosociologia, 29, 151-164.

ISPRA, 2010. Analisi conclusive relative alla cartografia Corine Land Cover 2000. ISPRA Rapporti, 130, $1-117$.

Jacobson R.B. and Galat D.L., 2006. Flow and form in rehabilitation of large-river ecosystems: an example from the Lower Missouri River. Geomorphology, 77, 249-269.

Jansson R., Nilsson C., Dynesius M. and Andersson E., 2000a. Effects of river regulation on river-margin vegetation: a comparison of eight boreal rivers. Ecol. Appl., 10, 203-224.

Jansson R., Nilsson C. and Renöfält B., 2000b. Fragmentation of riparian floras in rivers with multiple dams. Ecology, 81, 899-903.

Johansson M.E. and Nilsson C., 2002. Responses of riparian plants to flooding in free-flowing and regulated boreal rivers: an experimental study. J. Appl. Ecol., 39, 971-986.

Johnson W.C., 1999. Response of riparian vegetation to stream flow regulation and land use in the Great Plains. Gt Plains Res., 9, 357-369.

Johnson W.C., 2002. Riparian vegetation diversity along regulated rivers: contribution of novel and relict habitats. Freshwater Biol., 47, 749-759.

Krolová M., Čižková H., Hejzlar J. and Poláková S., 2013. Knowl. Managt. Aquatic Ecosyst., 408, 07.

Meffe G.K., 1984. Effects of abiotic disturbance on coexistence of predator-prey fish species. Ecology, $65,1525-1534$.

Minissale P. and Spampinato G., 1985. Osservazioni fitosociologiche sul Lago Gurrida (Sicilia N-O). Gior. Bot. Ital., 119, 197-225.

New T. and Xie Z., 2008. Impacts of large dams on riparian vegetation: applying global experience to the case of China's Three Gorges Dam. Biodivers. Conserv., 17, 3149-3163.

Nilsson C. and Berggren K., 2000. Alterations of riparian ecosystems caused by river regulation. Bioscience, 50, 783-792.

Nilsson C. and Jansson R., 1995. Floristic differences between riparian corridors of regulated and freeflowing boreal rivers. Regul. River. Res. Manage., 11, 55-66. 
Nilsson C., Jansson R. and Zinko U., 1997. Long-term responses of river-margin vegetation to waterlevel regulation. Science, 276, 798-800.

Nilsson C., Reidy C.A., Dynesius M., and Revenga C., 2005. Fragmentation and flow regulation of the world's large river systems. Science, 308, 405-408.

Pasternack G.B., Wang C.L. and Merz J.E., 2004. Application of a 2D hydrodynamic model to design of reach-scale spawning gravel replenishment on the Mokelumne River, California. River. Res. Appl., 20, 205-225.

Pedrotti F. and Orsomando E., 1982. Flore et végétation du Lac Trasiméne. In: Excursion internationale de Phytosociologie en Italie centrale (2-11 juillet 1982), Guide-itinéraire, Camerino, 469-478.

Poff N.L., Allan J.D., Bain M.B., Karr J.R., Prestegaard K.L., Richter B.D., Sparks R.E. and Stromberg J.C., 1997. The natural flow regime: a paradigm for river conservation and restoration. BioScience, 47, 769-784.

Regione Lazio, 2007. SIC-ZPS IT 6030012 "Riserva Naturale Tevere Farfa". Habitat e paesaggio. Due progetti di salvaguardia ambientale e riqualificazione del paesaggio agricolo storico, Arpinate Stampa S.R.L., Arpino (FR), 70 p.

Richter B.D., Baumgartner J.V., Powell J. and Braun D.P., 1996. A method for assessing hydrologic alteration within ecosystems. Conserv. Biol., 10, 1163-1174.

Roy A.H., Freeman M.C., Freeman B.J., Wenger S.J., Ensign W.E. and Meyer J.L., 2005. Investigating hydrologic alteration as a mechanism of fish assemblage shifts in urbanizing streams. J. North American Benthol. Soc., 24, 656-678.

Sambucini V., Marinosci I., Bonora N. and Chirici G., 2010. La realizzazione in Italia del Progetto europeo Corine Land Cover 2006. ISPRA Rapporti, 131.

Scott M.L., Auble G.T. and Friedman J.M., 1997. Flood dependency of cottonwood establishment along the Missouri River, Montana, USA Ecol. Appl., 7, 677-690.

Spada F., 2006. Carta della vegetazione della Riserva Naturale Regionale "Tevere-Farfa" scala 1:10.000, Regione Lazio, R.N.R. Tevere Farfa.

Spada F. and Casella L., 2006. Memoria illustrativa alla Carta della Vegetazione SIC/ZPS IT 6030012 "Riserva Naturale Tevere Farfa", Regione Lazio Parchi e Riserve Naturali, R.N.R. Tevere-Farfa, $36 \mathrm{p}$.

Springuel I., El-Hadidi M.N. and Ali M.M., 1991. Vegetation gradient on the shores of Lake Nasser in Egypt. Vegetatio, 94, 15-23.

Springuel I., Sheded M. and Murphy K.J., 1997. The plant biodiversity of the Wadi Allaqi Biosphere Reserve (Egypt): impact of Lake Nasser on a desert wadi ecosystem. Biodivers. Conserv., 6, $1259-1275$.

Stromberg J.C., Lite S.J., Marler R., Paradzick C., Shafroth P.B., Shorrock D., White J.M. and White M.S., 2007. Altered stream-flow regimes and invasive plant species: the Tamarix case. Global Ecol. Biogeogr., 16, 381-393.

Tharme R.E., 2003. A global perspective on environmental flow assessment: emerging trends in the development and application of environmental flow methodologies for rivers. River. Res. Appl., 19, 397-441.

The Nature Conservancy, 2009. Indicators of Hydrologic Alteration Version 7.1 - User's Manual. 81 p.

Thorne C.R., 1997. Channel types and morphological classification. In: Thorne C.R., Hey R.D. and Newson M.D. (Eds.), Applied Fluvial Geomorphology for River Engineering and Management, John Wiley \& Sons Ltd., 175-222.

Townsend C., Scarsbrook M. and Doledec S., 1997. Quantifying disturbance in streams: alternative measures of disturbance in relation to macroinvertebrate species traits and species richness. J. North American Benthol. Soc., 16, 531-544.

Venanzoni R., Apruzzese A., Gigante D., Suanno G. and Vale F., 2003. Contributo alla conoscenza della vegetazione acquatica e igrofitica del Laghi di Monticchio. Inf. Bot. Ital., 35, 69-80.

Venanzoni R. and Gigante D., 2000. Contributo alla conoscenza della vegetazione degli ambienti umidi dell'Umbria. Fitosociologia, 37, 13-63.

Walling D.E and Webb W., 1996. Erosion and sediment yield: a global overview. In: Walling D.E. and Webb B.W. (eds.), Erosion and sediment yield: global and regional perspectives. Proceed Exeter Symposium, 236, IAHS Press, Wallingford, 3-20.

Wootton J.T., Parker M.S. and Power M.E., 1996. Effects of disturbance on river food webs. Science, 273, 1558-1561.

Zhang Q. and Lou Z., 2011. The environmental changes and mitigation actions in the Three Gorges Reservoir region, China. Environ Science Policy, 14, 1132-1138. 